\title{
Probiotics in the gut-skin axis - the case of kefir
}

\author{
Probióticos no eixo intestino-pele - o caso do kefir
}

\author{
Emilia Alves ${ }^{1,2}$, Patrícia Rijo ${ }^{1,3}$, Luís Monteiro Rodrigues ${ }^{198}$, Catarina Rosado ${ }^{1 * 98}$
}

${ }^{1}$ CBIOS - Universidade Lusófona's Research Center for Biosciences and Health Technologies, Av. Campo Grande 376, 1749024 Lisbon, Portugal; ${ }^{2}$ Department of Biomedical Sciences, Faculty of Pharmacy, University of Alcalá, Campus Universitario, 28871 Alcalá de Henares, Spain; ${ }^{3}$ Instituto de Investigação do Medicamento (iMed.ULisboa), Faculdade de Farmácia,

Universidade de Lisboa, 1649-003 Lisbon, Portugal

*corresponding author / autor para correspondência: catarina.rosado@ulusofona.pt

Hshared senior mentorship / supervisão senior partilhada

\begin{abstract}
The intestinal microbiota is linked to important functions in the host. Alterations in its composition and/or its byproducts, causing loss of homeostasis, contribute to dysfunctions in other organic systems, including the skin, hence suggesting a gut-skin relationship. The oral administration of probiotics, widely associated with improved intestinal health, can act through an immunomodulatory response, both locally and systemically, presenting itself as potentially beneficial in inflammatory skin diseases such as atopic dermatitis. Traditional kefir, consumed for centuries as a health-promoting natural food, has its biological activity attributed both to the presence of a complex microbiota and to the action of the metabolites released during fermentation. The biological activity of kefir has been demonstrated in part by its ability to positively impact the intestinal microbiota, mainly based on animal models and in vitro, thus providing limited information. The nutritional and microbiological value of kefir makes its application as a probiotic in the gut-skin relationship a topic of of significant interest.

This review aimed to explore the impact of probiotics as regulators of the gut-skin axis, focusing on the current knowledge of kefir as a health-promoting food.
\end{abstract}

Keywords: kefir, probiotic, gut-skin axis, skin health, atopic dermatitis

\begin{abstract}
Resumo
Amicrobiota intestinal estáligada importantes funções no hospedeiro. Alterações em sua composiçãoe / ou subprodutos, causando perda da homeostase, contribuem para disfunções em outros sistemas orgânicos, incluindo a pele, sugerindo uma relação intestino-pele. A administração oral de probióticos, amplamente associada à melhora da saúde intestinal, pode atuar por meio de uma resposta imunomoduladora, quer local quer sistemicamente, apresentando-se como potencialmente benéfica em doenças inflamatórias da pele como a dermatite atópica. $\mathrm{O}$ kefir tradicional, consumido durante séculos como um alimento natural promotor de saúde, tem a sua actividade biológica atribuída à presença de uma microflora complexa, bem como à acção dos metabolitos libertados durante a fermentação. A actividade biológica de kefir parcialmente demonstrada pela sua capacidade de influenciar positivamente a microbiota intestinal, tem sido baseada principalmente em modelos animais e in vitro, proporcionando assim informação limitada. $\mathrm{O}$ valor nutricional e microbiológico do kefir torna sua aplicação como um probiótico na relação intestino-pele de grande interesse.

Esta revisão teve como objetivo explorar o impacto dos probióticos enquanto reguladores do eixo intestino-pele, focando o conhecimento atual do kefir como um alimento promotor de saúde.
\end{abstract}

Palavras-chave: kefir, probiótico, eixo intestino-pele, saúde da pele, dermatite atópica 


\section{Introduction}

The adult human intestine includes a complex ecosystem of microorganisms referred to as gut microbiota (1). The intestinal microbiota is linked to important functions in the host, including digestion of fermentable carbohydrates into short-chain fatty acids (SCFAs) used as an energy source for intestinal cells; production of key nutrients such as essential vitamins and amino acids; protection against pathogens and regulation of the immune system $(2,3,4,5)$. Under normal conditions, intestinal barrier function is highly efficient due to a complex network of mechanisms including a mucus layer, junction proteins, antimicrobial factors, and adaptive immune cells $(5,6)$. However, changes in both the quantitative and qualitative composition of the microbiota, designated as intestinal dysbiosis, potentiates the disruption of these conditions, resulting in loss of homeostasis and, consequently, contributing to a disease state $(4,7,8,9)$. This connection between the gut microbiome and human health foresees that the factors affecting microbial composition can indirectly modulate disease states. Among these, the inclusion of probiotics in the host's diet plays a prominent role, both for its nutritional value and easy digestion, and for the growing predisposition of individuals to consume foods perceived as healthy $(3,6,10,11,12)$. Traditional kefir, originating in the Caucasus Mountains, has been consumed for centuries. Current knowledge supports the historical consideration of kefir as a healthpromoting natural food $(13,14,15)$, and this review aimed to explore the impact of probiotics from kefir as regulators of the gut-skin axis.

\section{Gut-Skin Axis}

The intestinal microbiota and its by-products have been shown to affect other organic systems, including the skin, thus demonstrating the existence of a gut-skin relationship $(16,17,18)$. This influence can manifest itself directly via modulation of the immunological response, or indirectly through the secretory activity of the intestinal epithelium and the impact of the host's $\operatorname{diet}(19,20,21)$.

Alterations in the balance of the gut-skin relationship are associated with dysfunctions both at the gastrointestinal and skin levels. Changes in the intestinal microbiota associated with increased intestinal permeability can impact the immune system, thus promoting systemic inflammation, and allowing the direct migration of

\section{Introdução}

$\mathrm{O}$ intestino humano adulto inclui um ecossistema complexo de microrganismos conhecidos como microbiota intestinal (1). A microbiota intestinal está ligada a funções importantes no hospedeiro, como digestão de hidratos de carbono fermentáveis em ácidos gordos de cadeia curta (AGCCs) que são usados como fonte de energia para as células intestinais; produção de nutrientes, como síntese de vitaminas e aminoácidos essenciais; proteção contra patógenos e regulação do sistema imunológico $(2,3,4,5)$. Em condições normais, a função da barreira intestinal é altamente eficiente devido a uma complexa rede de mecanismos como a presença de uma camada de muco, proteínas de junção, fatores antimicrobianos e células imunes adaptativas $(5,6)$. Porém, alterações, quer quantitativas quer qualitativas, na composição da microbiota, denominadas disbiose intestinal, potenciam a perturbação dessas condições, resultando na perda da homeostase, contribuindo consequentemente para o estado de doença $(4,7,8,9)$. Esta conexão entre o microbioma intestinal e a saúde humana prevê que os fatores que afetam a composição microbiana possam indiretamente modular os estados de doença. Dentre estes, a dieta do hospedeiro, incluindo a ingestão de probióticos, desempenha papel de destaque, tanto pelo seu valor nutricional e de fácil digestão, quanto pela crescente predisposição dos indivíduos a consumir alimentos percebidos como saudáveis $(3,6,10,11,12)$. O kefir tradicional, originário da Cordilheira do Cáucaso, é consumido há séculos. O conhecimento atual corrobora a visão histórica do kefir como um alimento natural promotor da saúde $(13,14,15)$, pelo que esta revisão teve como objetivo explorar o impacto dos probióticos do kefir como reguladores do eixo intestino-pele.

\section{Eixo intestino-pele}

A microbiota intestinal e seus subprodutos têm a capacidade de afetar outros sistemas orgânicos, incluindo a pele, demonstrando assim a existência de uma relação intestino-pele $(16,17,18)$. Essa influência pode manifestar-se diretamente pela modulação da resposta imunológica, ou indiretamente, pela atividade secretora do epitélio intestinal e pelo impacto da dieta do hospedeiro $(19,20,21)$. Alterações no equilíbrio da relação intestino-pele estão associadas a disfunções tanto no nível gastrointestinal quanto na pele. Alterações na microbiota intestinal associadas ao aumento da permeabilidade intestinal podem impactar o sistema 
inflammatory products into the circulation. When these products reach the skin, skin homeostasis can be impaired, thus reinforcing the existence of a link between the intestinal microbiota and dermatological diseases $(1,3,4,22,23)$. Although the mechanisms of action are still unclear, considering the current knowledge, the response to intestinal environmental changes seems to involve a combination of factors that lead to a state of systemic inflammation, thus affecting the skin. Moreover, intestinal dysbiosis has been found to be a common factor in inflammatory skin diseases such as atopic dermatitis, rosacea, acne, and psoriasis, thus supporting the bidirectionality of this axis $(22,24,25,26)$.

\section{Probiotics in the modulation of the gut}

By definition, probiotics are live microorganisms that confer a health benefit to the host when administered in adequate amounts (27). However, growing evidence suggests that non-microbial components, such as microbial metabolites and cell wall compounds, can also positively affect human health $(16,28,29)$. In addition to their nutritional benefits, the use of probiotics has been widely associated with improved intestinal health, whether by improving the intestinal barrier function, modulating the immune system and antimicrobial effect against intestinal pathogens, or by producing metabolites with anti-inflammatory action, such as SCFA acetate, propionate, and butyrate $(5,28,30,31,32,33,34,35)$. The mechanisms of action, however, have yet to be fully identified. Moreover, no product with health claims associated with the administration of probiotics has yet been approved by the European Food Security Authority (EFSA) (36).

\section{Probiotics and skin health}

The integrity of the skin barrier is critical for skin defense and immune performance $(35,37,38)$. Immune skin diseases such as rosacea, acne, and atopic dermatitis are associated with the breakdown of the skin barrier, whereas its restoration is associated with an improvement in clinical outcomes $(38,39,40,41)$.

Probiotics can modulate the immune response locally or systemically $(1,6,23,24,40)$. Topical application of probiotics reduces pro-inflammatory molecules, hence controlling the spread of skin inflammation in acne, and produces anti-inflammatory molecules via imunológico, promovendo inflamação sistémica, além de permitir a migração direta de produtos inflamatórios para a circulação. Quando esses produtos atingem a pele pode ocorrer perturbação na homeostase cutânea, reforçando a existência de um elo entre a microbiota intestinal e as doenças dermatológicas $(1,3,4,22,23)$. Embora os mecanismos de ação ainda sejam obscuros, considerando-se os conhecimentos atuais, a resposta às alterações ambientais intestinais parece envolver uma combinação de fatores que levam a um estado de inflamação sistémica, afetando a pele. Além disso, em doenças inflamatórias da pele como dermatite atópica, rosácea, acne e psoríase, a disbiose intestinal é considerada um fator comum, apoiando desse modo a bidirecionalidade deste eixo $(22,24,25,26)$.

\section{Probióticos na modulação do intestino}

Probióticos são, por definição, microrganismos vivos que, quando administrados em quantidades adequadas, conferem benefício à saúde do hospedeiro (27). No entanto, evidências crescentes sugerem que componentes não microbianos, como metabolitos microbianos e compostos da parede celular, também podem afetar positivamente a saúde humana $(16,28,29)$. O uso de probióticos, além dos seus benefícios nutricionais, tem sido amplamente associado à melhoria da saúde intestinal, seja pela melhoria da função de barreira intestinal, pela modulação do sistema imunológico e pelo efeito antimicrobiano contra patógenos intestinais, seja pela produção de metabolitos com ação antiinflamatória, como os AGCC, acetato, propionato e butirato, apesar dos seus mecanismos de ação não estarem ainda totalmente identificados $(5,28,30,31,32,33,34,35)$. Além disso, nenhum produto com alegações de saúde associadas à administração de probióticos foi ainda aprovado pela Autoridade Europeia de Segurança Alimentar (EFSA) (36).

\section{Probióticos e a saúde da pele}

A integridade da barreira cutânea é crítica para a defesa da pele e para o desempenho imunológico $(35,37,38)$. Doenças imunológicas da pele, como rosácea, acne e dermatite atópica, estão associadas à quebra da barreira cutânea, enquanto que a sua restauração está associada a uma melhoria nos desfechos clínicos $(38,39,40,41)$. Os probióticos podem modular a resposta imune, local ou sistemicamente $(1,6,23,24,40)$. A aplicação 
dendritic cells in atopic dermatitis (AD) $(16,22,42)$. In addition to improving the intestinal barrier function, oral administration of probiotics can modulate the immune response and reduce systemic inflammation, thereby improving skin health through the gut-skin axis $(22,23,41)$. Research on the contribution of probiotics to skin health has focused on skin conditions such as $\mathrm{AD}$, acne, wound healing, and skin barrier improvement $(17,18,22,26,41,43,44)$. Furthermore, increasing evidence suggests that in addition to the microbial effect, non-microbial components such as microbial metabolites and cell wall compounds may also have beneficial effects, including benefits to skin health $(16,28,29,45)$.

\section{Immunological modulation of probiotics and skin health}

The immunological impact of probiotics has been demonstrated by their ability to upregulate regulatory $\mathrm{T}$ cells (Treg) and Type-1 T-helper (Th1) cells, responsible for the production of anti-inflammatory cytokines such as interleukin-10 (IL-10), in addition to their ability to downregulate Type-2 and Type-17 T-helper cells (Th2 and Th17, respectively) responsible for the production of pro-inflammatory cytokines such as interferon (INF)- $\gamma$, interleukin-4 (IL-4) and interleukin-5 (IL5) $(5,46)$. Furthermore, probiotics also suppress the maturation of dendritic cells leading to inhibition of naive $\mathrm{T}$ cell differentiation into $\mathrm{Th} 2$ cells, thus fighting skin inflammation $(35,47,48,49)$.

The role of microbial metabolites of probiotics in skin health

Several bacterial metabolites can enhance immunological response, thus leading to beneficial dermal effects (29). Lactic acid is the major product of metabolization of carbohydrates by either homoor heterofermentative lactic-acid bacteria (LAB), which can be produced in sufficient concentrations to exhibit antibacterial activity against most pathogenic dermal bacteria $(29,45,50,51)$. Lactic acid has been documented as part of the natural moisturizing factor (NMF) that retains moisture in the skin, and it plays important roles in the physical properties of the stratum corneum (29). Acetic acid, also produced by heterofermentative $\mathrm{LAB}$, has been shown to exert antibacterial effects on different bacterial species, likely due to its $\mathrm{pH}$ lowering capability, thereby creating an environment unsuitable for pathogen growth $(29,45)$. Diacetyl can also be produced by some strains of Lactobacilli and Bifidobacteria at concentrations that tópica de probióticos reduz a produção de moléculas pró-inflamatórias, controlando assim a propagação da inflamação da pele no acne, além de produzir moléculas anti-inflamatórias, via células dendríticas, na dermatite atópica (DA) $(16,22,42)$. A administração oral de probióticos, além de melhorar a função de barreira intestinal, pode modular a resposta imune e reduzir a inflamação sistémica, melhorando a saúde da pele através do eixo intestino-pele $(22,23,41)$. Pesquisas sobre a contribuição dos probióticos para a saúde da pele focaram doenças da pele como DA, acne, cicatrização de feridas e melhoria da barreira cutânea $(17,18,22,26,41,43,44)$. Adicionalmente, evidências crescentes sugerem que, além do efeito microbiano, componentes não microbianos, como metabolitos microbianos e compostos da parede celular, também podem exercer efeitos benéficos para a saúde, inclusive na saúde da pele $(16,28,29,45)$.

\section{Modulação imunológica de probióticos e saúde da pele}

O impacto imunológico dos probióticos tem sido demonstrado pela sua capacidade de regular positivamente as células $\mathrm{T}$ reguladoras (Treg) e as células $\mathrm{T}$ auxiliares do tipo 1 (Th1), responsáveis pela produção de citocinas antiinflamatórias, como a interleucina-10 (IL-10), além de regular negativamente as células $\mathrm{T}$ auxiliaries do tipo 2 (Th2) e do tipo 17 (Th17), responsáveis pela produção de citocinas próinflamatórias, como interferon (INF)- $\gamma$, interleucina-4 (IL-4) e interleucina-5 (IL-5) $(5,46)$. Adicionalmente, os probióticos também suprimem a maturação das células dendríticas, levando à inibição da diferenciação das células T naïve em células Th2, combatendo assim a inflamação da pele $(35,47,48,49)$.

\section{O papel dos metabólitos microbianos dos probióticos na saúde da pele}

Vários metabolitos bacterianos podem aumentar a resposta imunológica, conduzindo a efeitos dérmicos benéficos (29). O ácido láctico é o principal produto da metabolização de hidratos de carbono por bactérias ácido-lácticas homo e heterofermentativas (BAL), que podem produzi-lo em concentrações suficientes para exibir atividade antibacteriana contra a maioria das bactérias dérmicas patogénicas $(29,45,50,51)$. O ácido lático foi documentado como fazendo parte do fator de hidratação natural (NMF), que retém a humidade da pele e desempenha papéis importantes nas propriedades físicas do estrato córneo (29). O ácido acético, também produzido por BAL heterofermentativas, demonstrou exercer efeitos antibacterianos em diferentes espécies 
suggest its potential dermal antimicrobial activities (45). Lipoteichoic acid (ALT) and peptidoglycan (PG) are structural components of cell walls and play a vital role in their growth and physiology, with evidence that their production by LAB can be sufficient to increase the dermal cell defense against bacterial infection $(29,45)$. Moreover, PG from Lactobacilli demonstrated the ability to stimulate an immune response, thus contributing to skin protection $(2,9,23)$, and can be effective even at low concentrations by synergism with LTA (25). Hyaluronic acid (HA), widely utilized in dermatology as a biomaterial and in the promotion of wound healing due to its highly osmotic nature, is relevant in controlling tissue hydration during inflammatory processes (52). To date, only certain strains of Lactobacilli are known to produce HA (45). Finally, sphingomyelinase (SMase), an enzyme that generates ceramides and sphingomyelin precursors necessary for the development of extracellular lipid bilayers in the stratum corneum, has demonstrated important activity for skin barrier function $(29,53)$. SMase can be produced by strains of Lactobacilli and Bifidobacteria at sufficient concentrations to promote ceramide production in skin cells with the possibility to improve barrier properties (45).

\section{Probiotics in Atopic Dermatitis}

$\mathrm{AD}$ is a chronic inflammatory skin disease associated with an exacerbated skin response to environmental agents that, together with the disruption of the skin barrier integrity, promote a decrease in the antimicrobial response, thus enabling abnormal skin inflammation $(38,54)$. Although the etiology remains unclear, AD onset points towards a complex interaction between skin barrier dysfunction, immune dysregulation, environmental risk factors, and dysbiosis of the intestinal and skin microbiota, which correlates with its clinical severity $(54,55,56,57)$.

Immunological imbalance has been reported in AD patients, namely a decrease in Treg cells and an increase in Th2 cells and Th17 cells in the acute phase of the disease, whereas Th1 cells were associated with the chronic phase $(23,26)$. Th17 cells were also positively correlated with AD severity (58). Current research has focused on the immunomodulatory effect of probiotics, as they are able to stimulate Treg cells and suppress Th2 cells mediated responses, which are the predominant immune responses in $\mathrm{AD}$ $(23,26,41,46,59,60,61,62,63)$. However, evidence supporting their use for the treatment and prevention of $\mathrm{AD}$ is limited $(40,41,61,64,65,66,67,68)$. bacterianas, provavelmente devido à sua capacidade de diminuir o $\mathrm{pH}$, criando assim um ambiente inadequado para o crescimento de patógenos $(29,45)$. Também o diacetil pode ser produzido por algumas estirpes de Lactobacilli e Bifidobacteria em concentrações que sugerem sua potencial atividade antimicrobiana dérmica (45). O ácido lipoteicóico (ALT) e o peptidoglicano (PG) são componentes estruturais das paredes celulares bacterianas e desempenham um papel vital no seu crescimento e fisiologia, existindo evidência de que a sua produção por BAL consegue atingir quantidades suficientes para aumentar a defesa celular dérmica contra infecção bacteriana $(29,45)$. Adicionalmente, o PG de Lactobacilli demonstrou capacidade para estimular a resposta imune, contribuindo assim para a proteção da pele $(2,9,23)$, podendo ainda ser eficaz mesmo em baixas concentrações por sinergismo com o LTA (25). O ácido hialurónico (AH), amplamente utilizado na dermatologia como biomaterial e também na promoção da cicatrização de feridas devido à sua natureza altamente osmótica, é relevante no controle da hidratação dos tecidos durante os processos inflamatórios (52). Até o momento, apenas certas estirpes de Lactobacilli são conhecidas por produzir AH (45). Por fim, a esfingomielinase (SMase), uma enzima que gera ceramidas e precursores de esfingomielina para o desenvolvimento de bicamadas lipídicas extracelulares no estrato córneo, demonstrou atividade importante para a função de barreira da pele $(29,53)$. SMase pode ser produzida por estirpes de Lactobacilli e Bifidobacteria em concentrações suficientes para promover a produção de ceramidas nas células da pele com a possibilidade de melhorar as propriedades de barreira (45).

\section{Probióticos na Dermatite Atópica}

A DA é uma doença inflamatória crónica da pele associada a uma resposta exacerbada da pele a agentes ambientais que, juntamente com a quebra da integridade da barreira cutânea, promovem uma diminuição na resposta antimicrobiana, possibilitando, assim, uma inflamação cutânea anormal $(38,54)$. Embora a etiologia permaneça obscura, o início da DA aponta para uma complexa interação entre a disfunção da barreira cutânea, a desregulação imunológica, fatores de risco ambientais e disbiose da microbiota intestinal e cutânea, que se correlacionam com a sua gravidade clínica $(54,55,56,57)$.

Desequilíbrios imunológicos têm sido relatados em pacientes com DA, nomeadamente a diminuição das células Treg e o aumento das células Th2 e Th17, na 
The composition of the gut microbiota has been shown to be different in AD patients, which helps support the hypothesis that aberrant gut microbiota may underlie the onset or worsening of AD $(23,59,69)$. Through the gut-skin axis, intestinal dysbiosis has the ability to negatively impact skin function, either by increasing epithelial permeability via pro-inflammatory cytokines, thus promoting immune dysregulation and contributing to the chronic systemic inflammation in $\mathrm{AD}$, or by perpetuating pruritus via secretion of neuroendocrine itch mediators, leading to a chronic itch-scratch cycle, thus further disrupting the skin barrier $(47,54,70,71)$. Consequently, the gut-skin axis may be receptive to modulation via dietary modification, which represents a potential complementary alternative in AD therapy $(6,13)$. Despite growing evidence that probiotics can improve the intestinal disorders associated with $\mathrm{AD}$, their use has not always proven to be effective, as the observed decrease in gut permeability may be insufficient to cause a discernible disease improvement $(59,63,65)$.

To date, research conducted in vivo in human adults on the impact of probiotics on $\mathrm{AD}$ is scarce $(40,41,48,59,61)$. Typically studied probiotics are Lactobacillus, Bifidobacterium and Saccharomyces boulardii, both isolated or in combination. In this sense, and due to the lack of consistency of the results obtained, it is plausible that some of the observed effects may be dependent on strains or species used, as well as on the microbial diversity and potential synergisms between microbes $(26,44,63,72,73,74)$. fase aguda da doença, enquanto as células Th1 foram associadas à sua fase crónica $(23,26)$. As células Th17 também foram positivamente correlacionadas com a gravidade da DA (58). Investigação recente tem-se concentrado no efeito imunomodulador dos probióticos, face à sua capacidade de estimular as células Treg e suprimir as respostas mediadas pelas células Th2, que são as respostas imunes predominantes na DA $(23,26,41,46,59,60,61,62,63)$. No entanto, as evidências atuais que apoiam o seu uso para o tratamento e prevenção da DA são limitadas $(40,41,61,64,65,66,67,68)$.

A composição da microbiota intestinal mostrou ser diferente em pacientes com DA, o que ajuda a apoiar a hipótese de que uma microbiota intestinal aberrante pode estar subjacente ao início ou agravamento da DA $(23,59,69)$. Através do eixo intestino-pele, a disbiose intestinal tem a capacidade de impactar negativamente a função da pele, seja pelo aumento da permeabilidade epitelial via citocinas pró-inflamatórias, promovendo assim a desregulação imunológica e contribuindo para a inflamação sistémica crónica na DA, ou perpetuando o prurido via secreção de mediadores neuroendócrinos, levando a um ciclo crónico de prurido-coçar, danificando ainda mais a barreira da pele $(47,54,70,71)$. Consequentemente, o eixo intestino-pele pode ser receptivo à modulação por meio de alterações dietéticas, representando, portanto, uma potencial alternativa complementar na terapia da DA $(6,13)$. Apesar das evidências crescentes de que os probióticos podem melhorar os distúrbios intestinais associados à DA, a sua utilização nem sempre se mostrou eficaz, pois a diminuição observada na permeabilidade intestinal pode ser insuficiente para causar uma melhora perceptível da doença $(59,63,65)$.

Até o momento, pesquisas conduzidas in vivo, em humanos adultos, são escassas sobre o impacto dos probióticos na DA $(40,41,48,59,61)$. Os probióticos normalmente estudados são Lactobacillus, Bifidobacterium e Saccharomyces boulardii, geralmente isolados ou em combinação. Nesse sentido, e devido à falta de consistência dos resultados obtidos, é plausível que alguns dos efeitos observados possam ser dependentes de estirpes ou espécies usadas, bem como da diversidade microbiana, devido a possíveis sinergismos entre micróbios $(26,44,63,72,73,74)$. 


\section{Kefir, a traditional and trendy probiotic beverage}

Traditional kefir production uses kefir grains as a starter culture for the fermentation of milk, differentiating it from other fermented foods (75). The microorganisms present in the grains are responsible for the lactic, acetic, and alcoholic fermentation of the milk, originating a product with a viscous texture, a sour and slightly acidic taste, and a low alcohol and carbonation content (76,77). Although these microbiological mixtures may not be fully defined, this product is considered acceptable for human consumption by EFSA due to its long tradition of food production using the traditional fermentation substrate (e.g., cow milk) $(36,78)$.

Currently, the growing demand for healthy foods has encouraged the consumption of kefir, drawing the attention of the food industry into its industrial production. However, due to the microbiological complexity of the kefir grains, maintaining the product quality in industrial production is problematic (79). Additionally, secondary yeast fermentation during storage compromised attempts to package traditionally produced kefir, further contributing to limit its largescale production (80). Thus, pure cultures, composed of a mixture of bacteria with or without yeast, are used in current kefir-like industrial products. Despite their similar flavor, some of the health benefits typically ascribed to traditional kefir may not occur, in part due to this change in microbial diversity $(77,81,82)$.

The microbiological composition of the fermented beverage is different from that of the grains and varies depending on its origin and cultivation method $(75,83)$. The nutritional composition is influenced by the type of milk, the time and temperature of fermentation, and the storage conditions $(51,84,85)$. Even so, traditionally produced kefir fulfills both microbiological and nutritional requirements $(86,87)$.

The lactic acid produced by LAB and the presence of acetic acid produced by acetic-acid bacteria act as natural preservatives, resulting in a low contamination risk for the traditional homemade product $(31,88)$. LAB also contribute to the organoleptic properties of the beverage by producing volatile compounds (e.g., acetaldehyde and acetyl), exopolysaccharides, and free amino acids $(89,90)$. Yeasts produce alcohol and carbon dioxide that contribute to the characteristic mouth feel and taste of kefir (51). The biochemical composition of kefir is reflected in its nutritional value, which is typically around $3 \%$ protein, less than $10 \%$ fat, and at

\section{Kefir, uma bebida probiótica tradicional e moderna}

A produção tradicional de kefir usa grãos de kefir como cultura inicial para a fermentação do leite, diferenciando-o de outros alimentos fermentados (75). Os microrganismos presentes nos grãos são responsáveis pela fermentação láctica, acética e alcoólica do leite, originando um produto de textura viscosa, sabor azedo e ligeiramente ácido, baixo teor alcoólico e carbonatado $(76,77)$. Uma longa tradição de produção de alimentos usando essas misturas microbiológicas não totalmente definidas e sendo o substrato de fermentação consistente com essa tradição (por exemplo, leite de vaca), torna este produto como aceitável para consumo humano pela $\operatorname{EFSA}(36,78)$.

Atualmente, a crescente demanda por alimentos saudáveis tem estimulado o consumo do kefir, atraindo a atenção da indústria alimentar para sua produção industrial. No entanto, devido à complexidade microbiológica dos grãos de kefir, manter a qualidade do produto na produção industrial é problemático (79). Além disso, as tentativas de embalar o kefir tradicionalmente produzido foram comprometidas pela fermentação secundária de leveduras durante $o$ armazenamento, o que contribuiu ainda mais para limitar sua produção em larga escala (80). Assim, o uso de culturas puras, compostas por uma mistura de bactérias com ou sem leveduras, está na base dos atuais produtos industriais do tipo kefir. Apesar de seu sabor semelhante, alguns dos benefícios para a saúde, tipicamente atribuídos ao kefir tradicional, podem não ocorrer, em parte devido a esta diferença na diversidade microbiana $(77,81,82)$.

A composição microbiológica da bebida fermentada é diferente da dos grãos e varia em função da origem dos grãos e do seu método de cultura $(75,83)$. Já a composição nutricional é influenciada pelo tipo de leite, pelo tempo e temperatura de fermentação e pelas condições de armazenamento $(51,84,85)$. No entanto, o kefir tradicionalmente produzido cumpre os requisitos microbiológicos e nutricionais $(86,87)$.

$\mathrm{O}$ ácido lático produzido pelas $\mathrm{BAL}$, potencializado pela presença do ácido acético produzido por bactérias ácido-acéticas, atua como conservante natural, permitindo que o produto caseiro tradicional tenha baixo risco de contaminação $(31,88)$. As BAL também contribuiem para as propriedades organolépticas da bebida, produzindo compostos voláteis (por exemplo, acetaldeído e acetil), exopolissacarídeos e aminoácidos 
least $0.6 \%$ lactic acid, according to the Codex criteria (86). Kefir can be refrigerated to maintain a shelf life of $3-12$ days $(77,81,91)$.

\section{Health effects of kefir}

Several health-promoting properties have been ascribed to kefir consumption (14,50,51,84,92,93,94,95). However, to date, most studies have been conducted in vitro with undigested kefir, or in animal models, thus limiting the prediction of the biological activity of kefir in humans $(96,97,98)$. Among the reported health activities of kefir are the improved lactose digestion, hypocholesterolemic effect, reduction of insulin resistance and antihypertensive effect, antiinflammatory effect, antimicrobial activity, antioxidant activity, antitumor activity, endothelial dysfunction, wound healing, modulation of the immune system and inhibition of pathogenic microorganisms $(28,31,5$ $2,88,99,100,101,102,103,104)$. In vivo human studies using kefir, however scarce, have been able to support some of these health benefits such as anti-inflammatory activity, hypocholesterolemic effect, and intestinal integrity conditions $(107,109,126,127)$.

These putative beneficial health properties can be attributed both to the complex microbial fraction of kefir that has shown in vitro an ability to colonize the human gut and modulate intestinal microbiota composition $(98,112,124)$, and to the non-microbial fraction containing bioactive metabolites resulting from fermentation $(32,76,100,102,105,106)$, including lactic acid, acetic acid, ethanol and $\mathrm{CO}_{2}$, vitamins, peptides, polysaccharides (such as kefiran), bacteriocins, acetaldehyde and diacetyl $(74,98,108,110,111)$. The role of the lactic acid has been highlighted. In addition to down-regulating pro-inflammatory responses at intestinal level $(33,34,108)$, lactic acid can be used by the gut microbiota to produce acetate, propionate, and butyrate. These SCFAs are highly associated with intestinal health and the modulation of the immune response $(5,62,98,112)$. Furthermore, the antimicrobial capacity of kefir, mainly attributed to the presence of organic acids and other inhibitor compounds such as bacteriocins, has also been demonstrated in vitro $(28,31,106)$. Its peptides have been linked to antihypertensive, antimicrobial, immunomodulatory, and anti-oxidative properties $(14,108,113,114)$. Moreover, the water-soluble polysaccharide kefiran has demonstrated in vitro resistance to enzymatic intestinal hydrolysis $(77,89,108,115,116,117)$, therefore becoming available to act as a substrate to the beneficial gut microbiota (118). Additionally, anti-tumor, anti- livres $(89,90)$. As leveduras produzem álcool e dióxido de carbono que contribuem para a sensação na boca e sabor caracteristicos do kefir (51). A composição química do kefir reflete-se no seu valor nutricional, que é normalmente cerca de $3 \%$ de proteína, menos de $10 \%$ de gordura e pelo menos $0,6 \%$ de ácido lático, de acordo com os critérios do Codex (86). O kefir pode ser refrigerado mantendo uma vida útil de 3-12 dias $(77,81,91)$.

\section{Efeitos do kefir na saúde}

Várias propriedades de promoção da saúde foram atribuídas ao consumo de kefir $(14,50,51,84,92,93,94,95)$. No entanto, até o momento, a maioria dos estudos foi realizada in vitro usando kefir não digerido ou em modelos animais, limitando assim a previsão da atividade biológica do kefir em humanos $(96,97,98)$. Entre as atividades de saúde relatadas sobre o kefir estão a melhoria da digestão da lactose, efeito hipocolesterolémico, redução da resistência à insulina e efeito anti-hipertensivo, efeito antiinflamatório, atividade antimicrobiana, atividade antioxidante, atividade antitumoral, disfunção endotelial, cicatrização de feridas, modulação do sistema imunológico e inibição de microorganismos patogénicos $(28,31,52,88,99,1$ 00,101,102,103,104). Estudos in vivo, em humanos, usando kefir, embora escassos, têm sido capazes de apoiar alguns desses benefícios para a saúde, como a atividade antiinflamatória, efeito hipocolesterolémico e integridade das condições intestinais $(107,109,126,127)$.

Essas supostas propriedades benéficas para a saúde podem ser atribuídas tanto à complexa fração microbiana do kefir, que demonstrou, in vitro, uma capacidade de colonizar o intestino humano e modular a composição da microbiota intestinal $(98,112,124)$, quanto à fração não microbiana que contém todos os metabolitos bioativos resultantes da fermentação $(32,76,100,102,105,106)$, como ácido lático, ácido acético, etanol e $\mathrm{CO}_{2}$, vitaminas, peptídeos, polissacarídeos (como o kefirano), bacteriocinas, acetaldeído e diacetil $(74,98,108,110,111)$. O papel do ácido láctico tem sido destacado, pois além de regular as respostas pró-inflamatórias ao nível intestinal $(33,34,108)$, também pode ser usado pela microbiota intestinal para produzir acetato, propionato e butirato, que são AGCC altamente associados à saúde intestinal e à modulação da resposta imune $(5,62,98,112)$. Adicionalmente, a capacidade antimicrobiana do kefir, atribuída principalmente à presença de ácidos orgânicos e outros compostos inibidores, como bacteriocinas, também foi demonstrada in vitro $(28,31,106)$. Os seus peptídeos têm sido relacionados com propriedades anti-hipertensivas, 
fungal, anti-bacterial, anti-hypertensive, anti-glycemic, laxative, immunomodulatory, anti-inflammatory, healing, and antioxidant properties of kefiran have been reported $(100,102,116,118,119,120)$.

\section{Modulation of the gut by kefir}

The ability of kefir to positively impact both the intestinal microbiota and the general condition of the digestive system has been demonstrated in vitro, in animal models, and in a limited number of human trials, where its potent anti-inflammatory effect has been frequently noted $(93,96,98,108,112,121,122,123,124,125)$. Recent research in humans on the putative modulation of intestinal microbiota showed that after the consumption of kefir, individuals with metabolic syndrome presented positive correlations between the composition of the intestinal microbiota and improvement of the insulin profile, decreased levels of pro-inflammatory cytokines (such as Tumoral Necrosis Factor (TNF)- $\alpha$ and IFN- $\gamma$ ) and lower blood pressure (126). In addition, another study in humans demonstrated the ability of kefir to modulate the composition of the intestinal microbiota by increasing the concentration of serum zonulin, thus avoiding disruption of the intestinal permeability (109). Thereby, the positive impact of kefir in the host's gut microbiota suggests that regular kefir consumption may reduce the risk of intestinal dysbiosis and, consequently, could improve the outcome of diseases, such as those with an inflammatory component $(127,128)$.

\section{Effect of kefir on the skin}

Research regarding the impact of kefir on the skin thus far has been limited to in vitro and animal studies and to the beneficial effect of its topical application on wound healing $(52,102)$ and anti-inflammatory and antimicrobial activity $(52,102,119)$. A recent study exploring the impact of oral administration of a kefir yeast (Kazachstania turicensis) in AD using an animal model verified a beneficial effect on the modulation of the gut microbiota as well as in the immune response, thus increasing the potential of kefir as a possible application in $\mathrm{AD}$ (121).

Noteworthy, none of the in vivo human studies found in the literature assessed the impact of a diet containing traditionally homemade kefir as the probiotic, neither in healthy nor atopic skin $(5,112)$. antimicrobianas, imunomoduladoras e antioxidantes $(14,108,113,114)$. O polissacarídeo hidrossolúvel, kefirano, demonstrou in vitro resistência à hidrólise enzimática intestinal $(77,89,108,115,116,117)$, tornando-se, desse modo, disponível para atuar como um substrato para a microbiota intestinal benéfica (118). Por fim, o kefirano tem sido também evidenciado pelas suas propriedades antitumorais, antifúngicas, antibacterianas, anti-hipertensivas, anti-glicémicas, laxantes, imunomoduladoras, antiinflamatórias, cicatrizantes e antioxidantes $(100,102,116,118,119,120)$.

\section{Modulação do intestino pelo kefir}

A capacidade do kefir de impactar positivamente a microbiota intestinal e a condição geral do sistema digestivo foi demonstrada in vitro, em modelos animais e num número limitado de testes em humanos, onde o seu forte efeito antiinflamatório se destacou $(93,96,98$, $108,112,112,121,122,123,124,125)$. Pesquisas recentes em humanos sobre a potencial modulação da microbiota intestinal mostraram que, após o consumo do kefir, indivíduos com síndrome metabólica apresentaram correlações positivas entre a composição da microbiota intestinal e melhoria do perfil insulínico, diminuição de citocinas pró-inflamatórias (como a Tumoral Fator de necrose (TNF)- $\alpha$ e IFN- $\gamma$ ) e na pressão arterial (126). Adicionalmente, outro estudo em humanos foi capaz de demonstrar a capacidade do kefir em modular a composição da microbiota intestinal, aumentando a concentração de zonulina sérica, evitando assim a ruptura da permeabilidade intestinal (109). Deste modo, o impacto positivo do kefir na microbiota intestinal sugere a possibilidade de que o consumo regular de kefir pode reduzir o risco de disbiose intestinal e, consequentemente, melhorar o resultado de doenças, como aquelas com um carácter inflamatório $(127,128)$.

\section{Efeito do kefir na pele}

A investigação sobre o impacto do kefir na pele está até agora limitada a estudos in vitro e em animais, e ao efeito benéfico de sua aplicação tópica na cicatrização de feridas $(52,102)$ e atividade antiinflamatória e antimicrobiana $(52,102,119)$. Um estudo recente explorando o impacto da administração oral de uma levedura de kefir (Kazachstania turicensis) na DA, usando um modelo animal, verificou um efeito benéfico na modulação da microbiota intestinal, bem como na resposta imune, aumentando assim o potencial do kefir como uma possível aplicação em AD (121). 


\section{Conclusion}

This work provided an overview of the impact of probiotics on the gut, and their potential effects on the skin, as a gut-skin axis appears to exist. In addition, current knowledge regarding the role of probiotics in skin health was presented.

Intestinal dysbiosis promotes the occurrence of lowgrade systemic chronic inflammation; hence modulation of the intestinal microbiota may represent a promising strategy for the prevention and treatment of cutaneous and non-cutaneous disease states. The use of fermented foods with probiotic activity, such as kefir, may represent an excellent nutritionally based alternative therapeutic strategy via intestinal modulation. Kefir stands out as a probiotic with potential to regulate the gut-skin axis, both for its nutritional and microbiological value, and supported by the historical safety of its consumption and its wide availability and growing popularity. However, scientific literature regarding the impact of a diet containing kefir on skin health is limited, making it essential to identify the effects of kefir in greater depth, as well as its mechanisms of action, in well-controlled human intervention studies. Thus, this review demonstrates the need for further in vivo studies in humans to assess the impact of traditional kefir on skin conditions both in healthy and diseased skin, particularly in individuals presenting AD.

\section{Conflict of Interests}

The editors involved in this manuscripts' authorship had no participation in the review or decision process. All authors have stated that there are no financial and/or personal relationships that could represent a potential conflict of interest.

\section{Author Contributions Statement}

CR, LMR, PR and EA: conceptualization and study design; EA: drafting; EA, PR and CR: drafting editing and reviewing.
Digno de nota, nenhum dos estudos em humanos, in vivo, encontrados na literatura avaliou o impacto de uma dieta contendo kefir tradicionalmente produzido, como probiótico, quer em pele saudável, quer atópica $(5,112)$.

\section{Conclusão}

Este trabalho forneceu uma visão geral do impacto dos probióticos no intestino e dos seus potenciais efeitos na pele, dada a aparente existência de um eixo intestinopele. Além disso, foi fornecido o estado da arte sobre o papel dos probióticos na saúde da pele.

Adisbiose intestinal promove a ocorrência de inflamação crónica sistémica de baixo grau, portanto a modulação da microbiota intestinal pode representar uma estratégia interessante para a prevenção e tratamento de estados de doença, incluindo as cutâneas. O uso de alimentos fermentados com atividade probiótica, como o kefir, pode representar uma excelente alternativa de base nutricional, como modulador intestinal. O kefir destacase como um probiótico com potencial para regular o eixo intestino-pele, seja pelo seu valor nutricional e microbiológico, aliado à sua segurança evidenciada pelo seu histórico de consumo humano, seja pela sua ampla disponibilidade e crescente popularidade. No entanto, a literatura ainda é escassa sobre o impacto de uma dieta contendo kefir na saúde da pele, sendo imprescindível identificar todos os envolvidos nos efeitos do kefir, bem como os seus mecanismos de ação, em estudos de intervenção humana bem controlados. Assim, esta revisão demonstra a necessidade de mais estudos in vivo, em humanos, sobre o impacto do kefir tradicional nas condições da pele, tanto na pele saudável quanto na doente, particularmente naquela que apresenta DA.

\section{Conflito de interesses}

Os editores envolvidos na autoria deste manuscrito não participaram do processo de revisão ou decisão. Todos os autores afirmaram que não existem relações financeiras e / ou pessoais que possam representar um potencial conflito de interesses.

\section{Declaração sobre as contribuições do autor}

CR, LMR, PR e EA: conceptualização e desenho de estudo; EA: redação; EA, PR e CR: edição e revisão da redação. 


\section{References / Referências}

1. Salem, I., Ramser, A., Isham, N., \& Ghannoum, M. A. (2018). The gut microbiome as a major regulator of the gut-skin axis. Frontiers in Microbiology, 9, 1-14. https://doi.org/10.3389/fmicb.2018.01459

2. Hill, D. A., \& Artis, D. (2010). Intestinal Bacteria and the Regulation of Immune Cell Homeostasis. Annual Review of Immunology, 28, 623-667. https://doi.org/10.1146/annurev-immunol-030409-101330

3. Huttenhower, C., Gevers, D., Knight, R., Abubucker, S., Badger, J. H., Chinwalla, A. T., Creasy, H. H., Earl, A. M., Fitzgerald, M. G., Fulton, R. S., Giglio, M. G., Hallsworth-Pepin, K., Lobos, E. A., Madupu, R., Magrini, V., Martin, J. C., Mitreva, M., Muzny, D. M., Sodergren, E. J., ... White, O. (2012). Structure, function and diversity of the healthy human microbiome. Nature, 486(7402), $207-214$. https://doi.org/10.1038/nature11234

4. Clemente, J. C., Manasson, J., \& Scher, J. U. (2018). The role of the gut microbiome in systemic inflammatory disease. BMJ (Online), 360, 1-16. https://doi.org/10.1136/bmj.j5145

5. Plaza-Diaz, J., Ruiz-Ojeda, F. J., Gil-Campos, M., \& Gil, A. (2019). Mechanisms of Action of Probiotics. Advances in Nutrition, 10, S49-S66. https://doi.org/10.1093/advances/nmy063

6. Wieërs, G., Belkhir, L., Enaud, R., Leclercq, S., Philippart de Foy, J.-M., Dequenne, I., de Timary, P., \& Cani, P. D. (2020). How Probiotics Affect the Microbiota. Frontiers in Cellular and Infection Microbiology, 9. https://doi.org/10.3389/fcimb.2019.00454

7. Frick, J.-S., \& Autenrieth, I. B. (2013). The Gut Microflora and Its Variety of Roles in Health and Disease. In U. Dobrindt, J. H. Hacker, \& C. Svanborg (Eds.), Between Pathogenicity and Commensalism (pp. 273-289). Springer Berlin Heidelberg. https://doi. org/10.1007/82_2012_217

8. La Fata, G., Weber, P., \& Mohajeri, M. H. (2018). Probiotics and the Gut Immune System: Indirect Regulation. Probiotics and Antimicrobial Proteins, 1-11. https://doi.org/10.1007/s12602-017-9322-6

9. Wu, H. J., \& Wu, E. (2012). The role of gut microbiota in immune homeostasis and autoimmunity. Gut Microbes, 3(1), 4-14. https:// doi.org/10.4161/gmic. 19320

10. David, L. A., Maurice, C. F., Carmody, R. N., Gootenberg, D. B., Button, J. E., Wolfe, B. E., Ling, A. V, Devlin, A. S., Varma, Y., Fischbach, M. A., Biddinger, S. B., Dutton, R. J., \& Turnbaugh, P. J. (2014). Diet rapidly and reproducibly alters the human gut microbiome. Nature, 505(7484), 559-563. https://doi.org/10.1038/nature12820

11. Simonyte Sjödin, K., Vidman, L., Rydén, P., \& West, C. E. (2016). Emerging evidence of the role of gut microbiota in the development of allergic diseases. Current Opinion in Allergy and Clinical Immunology, 16(4), 390-395. https://doi.org/10.1097/ACI.0000000000000277

12. Sonnenburg, J. L., \& Bäckhed, F. (2016). Diet-microbiota interactions as moderators of human metabolism. Nature, 535(7610), 56-64. https://doi.org/10.1038/nature18846

13. Wouters, J. T. M., Ayad, E. H. E., Hugenholtz, J., \& Smit, G. (2002). Microbes from raw milk for fermented dairy products. International Dairy Journal, 12(2-3), 91-109. https://doi.org/10.1016/S0958-6946(01)00151-0

14. Bourrie, B. C. T., Willing, B. P., \& Cotter, P. D. (2016). The Microbiota and Health Promoting Characteristics of the Fermented Beverage Kefir. Frontiers in Microbiology, 7(647). https://doi.org/10.3389/fmicb.2016.00647

15. Vinderola, C. G., Duarte, J., Thangavel, D., Perdigón, G., Farnworth, E., \& Matar, C. (2005). Immunomodulating capacity of kefir. Journal of Dairy Research, 72(2), 195-202. https://doi.org/10.1017/S0022029905000828

16. Guéniche, A., Bastien, P., Ovigne, J. M., Kermici, M., Courchay, G., Chevalier, V., Breton, L., \& Castiel-Higounenc, I. (2010). Bifidobacterium longum lysate, a new ingredient for reactive skin. Experimental Dermatology, 19, e1-e8. https://doi.org/10.1111/j.16000625.2009.00932.x

17. Gueniche, A., Philippe, D., Bastien, P., Reuteler, G., Blum, S., Castiel-Higounenc, I., Breton, L., \& Benyacoub, J. (2014). Randomised double-blind placebo-controlled study of the effect of vbacillus paracasei NCC 2461 on skin reactivity. Beneficial Microbes, 5(2), 137-145. https://doi.org/10.3920/BM2013.0001

18. Poutahidis, T., Kearney, S. M., Levkovich, T., Qi, P., Varian, B. J., Lakritz, J. R., Ibrahim, Y. M., Chatzigiagkos, A., Alm, E. J., \& Erdman, S. E. (2013). Microbial symbionts accelerate wound healing via the neuropeptide hormone oxytocin. PLoS ONE, 8(10), e78898. https://doi.org/10.1371/journal.pone.0078898

19. Finch, J., Munhutu, M. N., \& Whitaker-Worth, D. L. (2010). Atopic dermatitis and nutrition. Clinics in Dermatology, 28(6), 605-614. https://doi.org/10.1016/j.clindermatol.2010.03.032

20. Kano, M., Masuoka, N., Kaga, C., Sugimoto, S., Iizuka, R., Manabe, K., Sone, T., Oeda, K., Nonoka, C., Miyazaki, K., \& Ishikawa, F. (2013). Consecutive Intake of Fermented Milk Containing Bifidobacterium breve Strain Yakult and Galacto-oligosaccharides Benefits Skin Condition in Healthy Adult Women. Bioscience of Microbiota, Food and Health, 21(1), 33-39. https://doi.org/10.12938/ bmfh.32.33

21. Miyazaki, K., Masuoka, N., Kano, M., \& Iizuka, R. (2014). Bifidobacterium fermented milk and galacto-oligosaccharides lead to improved skin health by decreasing phenols production by gut microbiota. Beneficial Microbes, 5(2), 121-128. https://doi.org/10.3920/ BM2012.0066

22. Bowe, W. P., Patel, N. B., \& Logan, A. C. (2014). Acne vulgaris, probiotics and the gut-brain-skin axis: From anecdote to translational medicine. Beneficial Microbes, 5(2), 185-199. https://doi.org/10.3920/BM2012.0060

23. Ellis, S. R., Nguyen, M., Vaughn, A. R., Notay, M., Burney, W. A., Sandhu, S., \& Sivamani, R. K. (2019). The skin and gut microbiome and its role in common dermatologic conditions. Microorganisms, 7(11), 1-19. https://doi.org/10.3390/microorganisms7110550

24 Al-Ghazzewi, F. H., \& Tester, R. F. (2014). Impact of prebiotics and probiotics on skin health. Beneficial Microbes, 5(2), 99-107. https:// doi.org/10.3920/BM2013.0040

25. Friedrich, A. D., Paz, M. L., Leoni, J., \& Maglio, D. H. G. (2017). Message in a bottle: Dialog between intestine and skin modulated by probiotics. International Journal of Molecular Sciences, 18(1067), 1-11. https://doi.org/10.3390/ijms18061067

26. Iemoli, E., Trabattoni, D., Parisotto, S., Borgonovo, L., Toscano, M., Rizzardini, Zg., Clerici, M., Ricci, E., Fusi, A., Vecchi, E. De, Piconi, S., \& Lorenzo, D. (2012). Probiotics reduce gut microbial translocation and improve adult atopic dermatitis. Journal of Clinical Gastroenterology, 46, S33-S40. https://doi.org/10.1097/MCG.0b013e31826a8468. 
27. Hill, C., Guarner, F., Reid, G., Gibson, G. R., Merenstein, D. J., Pot, B., Morelli, L., Canani, R. B., Flint, H. J., Salminen, S., Calder, P. C., \& Sanders, M. E. (2014). Expert consensus document: The international scientific association for probiotics and prebiotics consensus statement on the scope and appropriate use of the term probiotic. Nature Reviews Gastroenterology and Hepatology, 11, 506-514. https://doi.org/10.1038/nrgastro.2014.66

28. Iraporda, C., Abatemarco Júnior, M., Neumann, E., Nunes, Á. C., Nicoli, J. R., Abraham, A. G., \& Garrote, G. L. (2017). Biological activity of the non-microbial fraction of kefir: Antagonism against intestinal pathogens. Journal of Dairy Research, 84, 339-345. https:// doi.org/10.1017/S0022029917000358

29. Lew, L. C., \& Liong, M. T. (2013). Bioactives from probiotics for dermal health: Functions and benefits. Journal of Applied Microbiology, 114(5), 1241-1253. https://doi.org/10.1111/jam.12137

30. Vieira, A. T., Fukumori, C., \& Ferreira, C. M. (2016). New insights into therapeutic strategies for gut microbiota modulation in inflammatory diseases. Clinical \& Translational Immunology, 5(6), e87-e87. https://doi.org/10.1038/cti.2016.38

31. Garrote, G. L., Abraham, A. G., \& De Antoni, G. L. (2000). Inhibitory Power of Kefir: The Role of Organic Acids. Journal of Food Protection, 63(3), 364-369. https://doi.org/10.4315/0362-028X-63.3.364

32. Romanin, D., Serradell, M., González Maciel, D., Lausada, N., Garrote, G. L., \& Rumbo, M. (2010). Down-regulation of intestinal epithelial innate response by probiotic yeasts isolated from kefir. International Journal of Food Microbiology, 140, 102-108. https://doi. org/10.1016/j.ijfoodmicro.2010.04.014

33. Iraporda, C., Errea, A., Romanin, D. E., Cayet, D., Pereyra, E., Pignataro, O., Sirard, J. C., Garrote, G. L., Abraham, A. G., \& Rumbo, M. (2015). Lactate and short chain fatty acids produced by microbial fermentation downregulate proinflammatory responses in intestinal epithelial cells and myeloid cells. Immunobiology, 220(10) 1161-1169. https://doi.org/10.1016/j.imbio.2015.06.004

34. Iraporda, C., Romanin, D. E., Rumbo, M., Garrote, G. L., \& Abraham, A. G. (2014). The role of lactate on the immunomodulatory properties of the nonbacterial fraction of kefir. Food Research International, 62, 247-253. https://doi.org/10.1016/j.foodres.2014.03.003

35. Weaver, C. T., Elson, C. O., Fouser, L. A., \& Kolls, J. K. (2013). The Th17 pathway and inflammatory diseases of the intestines, lungs, and skin. Annual Review of Pathology: Mechanisms of Disease, 8(October 2012), 477-512. https://doi.org/10.1146/annurev-pathol-011110-130318

36. EFSA Panel on Dietetic Products, N. and A. (NDA). (2016). Guidance on the scientific requirements for health claims related to the immune system, the gastrointestinal tract and defence against pathogenic microorganisms. EFSA Journal, 14(1), 4369. https://doi.org/ https://doi.org/10.2903/j.efsa.2016.4369

37. Swamy, M., Jamora, C., Havran, W., \& Hayday, A. (2010). Epithelial decision makers: in search of the "epimmunome." Nature Immunology, 11(8), 656-665. https://doi.org/10.1038/ni.1905

38. Proksch, E., Fölster-Holst, R., Bräutigam, M., Sepehrmanesh, M., Pfeiffer, S., \& Jensen, J. M. (2009). Role of the epidermal barrier in atopic dermatitis: Academy CME. JDDG - Journal of the German Society of Dermatology, 7(10), 899-911. https://doi.org/10.1111/ j.1610-0387.2009.07157.x

39. Deng, Z., Chen, M., Xie, H., Jian, D., Xu, S., Peng, Q., Sha, K., Liu, Y., Zhang, Y., Shi, W., \& Li, J. (2019). Claudin reduction may relate to an impaired skin barrier in rosacea. The Journal of Dermatology, 46(4), 314-321. https://doi.org/https://doi.org/10.1111/13468138.14792

40. Rusu, E., Enache, G., Cursaru, R., Alexescu, A., Radu, R., Onila, O., Cavallioti, T., Rusu, F., Posea, M., Jinga, M., \& Radulian, G. (2019). Prebiotics and probiotics in atopic dermatitis (Review). Experimental and Therapeutic Medicine, 926-931. https://doi. org/10.3892/etm.2019.7678

41. Notay, M., Foolad, N., Vaughn, A. R., \& Sivamani, R. K. (2017). Probiotics, Prebiotics, and Synbiotics for the Treatment and Prevention of Adult Dermatological Diseases. American Journal of Clinical Dermatology, 18(6), 721-732. https://doi.org/10.1007/s40257-0170300-2

42. Gueniche, A., Knaudt, B., Schuck, E., Volz, T., Bastien, P., Martin, R., Röcken, M., Breton, L., \& Biedermann, T. (2008). Effects of nonpathogenic gram-negative bacterium Vitreoscilla filiformis lysate on atopic dermatitis: a prospective, randomized, double-blind, placebo-controlled clinical study. British Journal of Dermatology, 159(6), 1357-1363. https://doi.org/https://doi.org/10.1111/j.13652133.2008.08836.x

43. Nermes, M., Kantele, J. M., Atosuo, T. J., Salminen, S., \& Isolauri, E. (2011). Interaction of orally administered Lactobacillus rhamnosus GG with skin and gut microbiota and humoral immunity in infants with atopic dermatitis. Clinical and Experimental Allergy, 41, 370-377. https://doi.org/10.1111/j.1365-2222.2010.03657.x

44. Drago, L., Iemoli, E., Rodighiero, V., Nicola, L., De Vecchi, E., \& Piconi, S. (2011). Effects of Lactobacillus Salivarius LS01 (DSM 22775) Treatment on Adult Atopic Dermatitis: A Randomized Placebo-Controlled Study. International Journal of Immunopathology and Pharmacology, 24(4), 1037-1048. https://doi.org/10.1177/039463201102400421

45. Lew, L. C., Gan, C. Y., \& Liong, M. T. (2013). Dermal bioactives from lactobacilli and bifidobacteria. Annals of Microbiology, 63(3), 1047-1055. https://doi.org/10.1007/s13213-012-0561-1

46. Lolou, V., \& Panayiotidis, M. I. (2019). Functional role of probiotics and prebiotics on skin health and disease. Fermentation, 5(2), 1-17. https://doi.org/10.3390/fermentation5020041

47. Lee, S.-Y., Lee, E., Park, Y. M., \& Hong, S. J. (2018). Gut-Skin Axis in Atopic Dermatitis. Allergy, Asthma, and Immunology Research, 10(4), 354-362. https://www.ncbi.nlm.nih.gov/pmc/articles/PMC6021588/pdf/aair-10-354.pdf

48. Rather, I. A., Bajpai, V. K., Kumar, S., Lim, J., Paek, W. K., \& Park, Y. H. (2016). Probiotics and atopic dermatitis: An overview. Frontiers in Microbiology, 7(APR), 1-7. https://doi.org/10.3389/fmicb.2016.00507

49. Lise, M., Mayer, I., \& Silveira, M. (2018). Use of probiotics in atopic dermatitis. Revista Da Associacao Medica Brasileira, 64(11), 997-1001. https://doi.org/10.1590/1806-9282.64.11.997

50. Prado, M. R., Blandón, L. M., Vandenberghe, L. P. S., Rodrigues, C., Castro, G. R., Thomaz-Soccol, V., \& Soccol, C. R. (2015). Milk kefir: Composition, microbial cultures, biological activities, and related products. Frontiers in Microbiology, 6(1177). https://doi. org/10.3389/fmicb.2015.01177 
51. Rosa, D. D., Dias, M. M. S., Grześkowiak, Ł. M., Reis, S. A., Conceição, L. L., \& Peluzio, M. D. C. G. (2017). Milk kefir: Nutritional, microbiological and health benefits. Nutrition Research Reviews, 30(1), 82-96. https://doi.org/10.1017/S0954422416000275

52. Huseini, H. F., Rahimzadeh, G., Fazeli, M. R., Mehrazma, M., \& Salehi, M. (2012). Evaluation of wound healing activities of kefir products. Burns, 38, 719-723. https://doi.org/10.1016/j.burns.2011.12.005

53. Rerknimitr, P., Otsuka, A., Nakashima, C., \& Kabashima, K. (2018). Skin Barrier Function and Atopic Dermatitis. Current Dermatology Reports, 7(4), 209-220. https://doi.org/10.1007/s13671-018-0232-y

54. Stefanovic, N., Irvine, A. D., \& Flohr, C. (2021). The Role of the Environment and Exposome in Atopic Dermatitis. Current Treatment Options in Allergy, 8, 222-241. https://doi.org/10.1007/s40521-021-00289-9

55. Kim, D. W., Park, J. Y., Na, G. Y., Lee, S. J., \& Lee, W. J. (2006). Correlation of clinical features and skin barrier function in adolescent and adult patients with atopic dermatitis. International Journal of Dermatology, 45(6), 698-701. https://doi.org/10.1111/j.13654632.2005.02644.x

56. Kim, J., Kim, B. E., \& Leung, D. Y. M. (2019). Pathophysiology of atopic dermatitis: Clinical implications. Allergy and Asthma Proceedings, 40(2), 84-92. https://doi.org/10.2500/aap.2019.40.4202

57. Kim, B. E., \& Leung, D. Y. M. M. (2018). Significance of Skin Barrier Dysfunction in Atopic Dermatitis. Allergy, Asthma \& Immunology Research, 10(3), 207-215. https://doi.org/10.4168/aair.2018.10.3.207

58. Koga, C., Kabashima, K., Shiraishi, N., Kobayashi, M., \& Tokura, Y. (2008). Possible Pathogenic Role of Th17 Cells for Atopic Dermatitis. Journal of Investigative Dermatology, 128(11), 2625-2630. https://doi.org/10.1038/jid.2008.111

59. Makrgeorgou, A., Leonardi-Bee, J., Bath-Hextall, F. J., Murrell, D. F., Tang, M. L. K., Roberts, A., \& Boyle, R. J. (2018). Probiotics for treating eczema. Cochrane Database of Systematic Reviews, 2018(11). https://doi.org/10.1002/14651858.CD006135.pub3

60. Kim, H.-J., Kim, Y.-J., Kang, M.-J., Seo, J.-H., Kim, H.-Y., Jeong, S. K., Lee, S.-H., Kim, J.-M., \& Hong, S.-J. (2012). A novel mouse model of atopic dermatitis with epicutaneous allergen sensitization and the effect of Lactobacillus rhamnosus. Experimental Dermatology, 21(9), 672-675. https://doi.org/https://doi.org/10.1111/j.1600-0625.2012.01539.x

61. Kim, S. O., Ah, Y. M., Yu, Y. M., Choi, K. H., Shin, W. G., \& Lee, J. Y. (2014). Effects of probiotics for the treatment of atopic dermatitis: A meta-analysis of randomized controlled trials. Annals of Allergy, Asthma and Immunology, 113(2), 217-226. https://doi.org/10.1016/j. anai.2014.05.021

62. Smith, P. M., Howitt, M. R., Panikov, N., Michaud, M., Gallini, C. A., Bohlooly-Y, M., Glickman, J. N., \& Garrett, W. S. (2013). The Microbial Metabolites, Short-Chain Fatty Acids, Regulate Colonic T\&lt;sub\&gt;reg\&lt;/sub\&gt; Cell Homeostasis. Science, 341(6145), 569 LP - 573. https://doi.org/10.1126/science.1241165

63. Fang, Z., Lu, W., Zhao, J., Zhang, H., Qian, L., Wang, Q., \& Chen, W. (2020). Probiotics modulate the gut microbiota composition and immune responses in patients with atopic dermatitis: a pilot study. European Journal of Nutrition, 59(5), 2119-2130. https://doi. org/10.1007/s00394-019-02061-x

64. Garcia-Larsen, V., Ierodiakonou, D., Jarrold, K., Cunha, S., Chivinge, J., Robinson, Z., Geoghegan, N., Ruparelia, A., Devani, P., Trivella, M., Leonardi-Bee, J., \& Boyle, R. J. (2018). Diet during pregnancy and infancy and risk of allergic or autoimmune disease: A systematic review and meta-analysis. PLOS Medicine, 15(2), e1002507. https://doi.org/10.1371/journal.pmed.1002507

65. Zhao, M., Shen, C., \& Ma, L. (2018). Treatment efficacy of probiotics on atopic dermatitis, zooming in on infants: a systematic review and meta-analysis. International Journal of Dermatology, 57(6), 635-641. https://doi.org/https://doi.org/10.1111/ijd.13873

66. Huang, R., Ning, H., Shen, M., Li, J., Zhang, J., \& Chen, X. (2017). Probiotics for the Treatment of Atopic Dermatitis in Children: A Systematic Review and Meta-Analysis of Randomized Controlled Trials. Frontiers in Cellular and Infection Microbiology, 7, 392. https://doi.org/10.3389/fcimb.2017.00392

67. Pelucchi, C., Chatenoud, L., Turati, F., Galeone, C., Moja, L., Bach, J.-F., \& La Vecchia, C. (2012). Probiotics supplementation during pregnancy or infancy for the prevention of atopic dermatitis: a meta-analysis. Epidemiology (Cambridge, Mass.), 23(3), 402-414. https://doi.org/10.1097/ede.0b013e31824d5da2

68. Doege, K., Grajecki, D., Zyriax, B.-C., Detinkina, E., zu Eulenburg, C., \& Buhling, K. J. (2012). Impact of maternal supplementation with probiotics during pregnancy on atopic eczema in childhood - a meta-analysis. British Journal of Nutrition, 107(1), 1-6. https://doi. org/DOI: 10.1017/S0007114511003400

69. Petersen, E. B. M., Skov, L., Thyssen, J. P., \& Jensen, P. (2018). Role of the gut microbiota in atopic dermatitis: A systematic review. Acta Dermato-Venereologica, 99(1), 5-11. https://doi.org/10.2340/00015555-3008

70. Kim, J., \& Kim, H. (2019). Microbiome of the Skin and Gut in Atopic Dermatitis (AD): Understanding the Pathophysiology and Finding Novel Management Strategies. Journal of Clinical Medicine, 8(4), 444. https://doi.org/10.3390/jcm8040444

71. O’Neill, C. A., Monteleone, G., McLaughlin, J. T., \& Paus, R. (2016). The gut-skin axis in health and disease: A paradigm with therapeutic implications. BioEssays, 38(11), 1167-1176. https://doi.org/10.1002/bies.201600008

72. Matsumoto, M., Ebata, T., Hirooka, J., Hosoya, R., Inoue, N., Itami, S., Tsuji, K., Yaginuma, T., Muramatsu, K., Nakamura, A., Fujita, A., \& Nagakura, T. (2014). Antipruritic effects of the probiotic strain LKM512 in adults with atopic dermatitis. Annals of Allergy, Asthma and Immunology, 113(2), 209-216.e7. https://doi.org/10.1016/j.anai.2014.05.002

73. Yoshida, Y., Seki, T., Matsunaka, H., Watanabe, T., Shindo, M., Yamada, N., \& Yamamoto, O. (2010). Clinical effects of probiotic bifidobacterium breve supplementation in adult patients with atopic dermatitis. Yonago Acta Medica, 53(2), 37-45. https://ci.nii.ac.jp/ naid/120002260982

74. Roessler, A., Friedrich, U., Vogelsang, H., Bauer, A., Kaatz, M., Hipler, U. C., Schmidt, I., \& Jahreis, G. (2008). The immune system in healthy adults and patients with atopic dermatitis seems to be affected differently by a probiotic intervention. Clinical and Experimental Allergy, 38(1), 93-102. https://doi.org/10.1111/j.1365-2222.2007.02876.x

75. Simova, E., Beshkova, D., Angelov, A., Hristozova, T., Frengova, G., \& Spasov, Z. (2002). Lactic acid bacteria and yeasts in kefir grains and kefir made from them. Journal of Industrial Microbiology and Biotechnology, 28(1), 1-6. https://doi.org/10.1038/sj/jim/7000186

76. Garrote, G. L., Abraham, A., \& De Antoni, G. L. (2001). Chemical and microbiological characterisation of kefir grains. Journal of Dairy Research, 68(4), 639-652. https://doi.org/10.1017\} S0022029901005210 
77. Otles, S., \& Cagindi, O. (2003). Kefir: A Probiotic Dairy-Composition, Nutritional and Therapeutic Aspects. Pakistan Journal of Nutrition, 2(2), 54-59. https://doi.org/10.3923/pjn.2003.54.59

78. Food and Drug Administration. (2016). Food Draft Guidance for Industry : Dietary Supplements : New Dietary Ingredient Notifications and Related Issues. In Center for Food Safety and Applied Nutrition. https://www.fda.gov

79. Vardjan, T., Mohar Lorbeg, P., Rogelj, I., \& Čanžek Majhenič, A. (2013). Characterization and stability of lactobacilli and yeast microbiota in kefir grains. Journal of Dairy Science, 96, 1-8. https://doi.org/10.3168/jds.2012-5829

80. Sarkar, S. (2008). Biotechnological innovations in kefir production: a review. British Food Journal, 110(3), 283-295. https://oi. org/10.1108/00070700810858691

81. Farnworth, E. R. (2005). Kefir - a complex probiotic. Food Science and Technology Bulletin: Functional Foods, 2(1), 1-17. https://doi. org/10.1616/1476-2137.13938

82. Leite, A. M. O., Leite, D. C. A., Del Aguila, E. M., Alvares, T. S., Peixoto, R. S., Miguel, M. A. L., Silva, J. T., \& Paschoalin, V. M. F. (2013). Microbiological and chemical characteristics of Brazilian kefir during fermentation and storage processes. Journal of Dairy Science, 96(7), 4149-4159. https://doi.org/10.3168/jds.2012-6263

83. Londero, A., Hamet, M. F., De Antoni, G. L., Garrote, G. L., \& Abraham, A. G. (2012). Kefir grains as a starter for whey fermentation at different temperatures: chemical and microbiological characterisation. Journal of Dairy Research, 79(3), 262-271. https://doi. org/10.1017/S0022029912000179

84. Nielsen, B., Gürakan, G. C., \& Ünlü, G. (2014). Kefir: A Multifaceted Fermented Dairy Product. Probiotics and Antimicrobial Proteins, 6, 123-135. https://doi.org/10.1007/s12602-014-9168-0

85. Garrote, G. L., Abraham, A. G., \& De Antoni, G. L. (1998). Characteristics of kefir prepared with different grain:milk ratios. Journal of Dairy Research, 65(1), 149-154. https://doi.org/10.1017/S0022029997002677

86. Codex Alimentarius International Food Standards. (2018). Codex standard for fermented milks (Codex Stan CXS 243-2003) (CAC (ed.)). World Health Organization (WHO) and Food and Agriculture Organization of the United Nations (FAO). http://www.fao.org/ fao-who-codexalimentarius/codex-texts/list-standards/en/

87. Alves, E., Ntungwe, E. N., Gregório, J., Rodrigues, L. M., Pereira-Leite, C., Caleja, C., Pereira, E., Barros, L., Aguilar-Vilas, M. V., Rosado, C., \& Rijo, P. (2021). Characterization of kefir produced in household conditions: Physicochemical and nutritional profile, and storage stability. Foods, 10(5), 1-16. https://doi.org/10.3390/foods 10051057

88. Hertzler, S. R., \& Clancy, S. M. (2003). Kefir improves lactose digestion and tolerance in adults with lactose maldigestion. Journal of the American Dietetic Association, 103(5), 582-587. https://doi.org/10.1053/jada.2003.50111

89. Rimada, P. S., \& Abraham, A. G. (2006). Kefiran improves rheological properties of glucono- $\delta$-lactone induced skim milk gels. International Dairy Journal, 16, 33-39. https://doi.org/10.1016/j.idairyj.2005.02.002

90. Guzel-Seydim, Z., Kok-Tas, T., Ertekin-Filiz, B., \& Seydim, A. C. (2011). Effect of different growth conditions on biomass increase in kefir grains. Journal of Dairy Science, 94(3), 1239-1242. https://doi.org/10.3168/jds.2010-3349

91. Rattray, F. P., \& O’Connell, M. J. (2011). Fermented Milks - Kefir. In M. P. Fuquay JW, Fox, PF (Ed.), Encyclopedia of Dairy Sciences. (pp. 518-524). Academic Press Inc.

92. Kesenkaş, H., Gürsoy, O., \& Özbaş, H. (2016). Kefir. In Fermented Foods in Health and Disease Prevention. https://doi.org/10.1016/ B978-0-12-802309-9.00014-5

93. Hsu, Y. J., Huang, W. C., Lin, J. S., Chen, Y. M., Ho, S. T., Huang, C. C., \& Tung, Y. T. (2018). Kefir supplementation modifies gut microbiota composition, reduces physical fatigue, and improves exercise performance in mice. Nutrients, 10(7). https://doi.org/10.3390/ nu10070862

94. Yang, Z., Zhou, F., Ji, B., Li, B., Luo, Y., Yang, L., \& Li, T. (2010). Symbiosis between microorganisms from kombucha and kefir: Potential significance to the enhancement of kombucha function. Applied Biochemistry and Biotechnology, 169, 446-455. https://doi. org/10.1007/s12010-008-8361-6

95. Guzel-Seydim, Z. B., Kok-Tas, T., Greene, A. K., \& Seydim, A. C. (2011). Review: Functional Properties of Kefir. Critical Reviews in Food Science and Nutrition, 51(3), 261-268. https://doi.org/10.1080/10408390903579029

96. Üstün-Aytekin, Ö., Şeker, A., \& Arısoy, S. (2020). The effect of in vitro gastrointestinal simulation on bioactivities of kefir. International Journal of Food Science and Technology, 55(1), 283-292. https://doi.org/10.1111/ijfs.14274

97. Garrote, G. L., Abraham, A. G., \& De Antoni, G. L. (2000). Inhibitory power of kefir: The role of organic acids. Journal of Food Protection, 63(3), 364-369. https://doi.org/10.4315/0362-028X-63.3.364

98. Slattery, C., Cotter, P. D., \& O'Toole, P. W. (2019). Analysis of health benefits conferred by Lactobacillus species from kefir. Nutrients, 11(6), 1-24. https://doi.org/10.3390/nu11061252

99. Liu, J. R., Chen, M. J., \& Lin, C. W. (2005). Antimutagenic and antioxidant properties of milk-kefir and soymilk-kefir. Journal of Agricultural and Food Chemistry, 53, 2467-2474. https://doi.org/10.1021/jf048934k

100. Maeda, H., Zhu, X., Omura, K., Suzuki, S., \& Kitamura, S. (2004). Effects of an exopolysaccharide (kefiran) on lipids, blood pressure, blood glucose, and constipation. BioFactors, 22(1-4), 197-200. https://doi.org/10.1002/biof.5520220141.

101. Huang, Y., Wang, X., Wang, J., Wu, F., Sui, Y., Yang, L., \& Wang, Z. (2013). Lactobacillus plantarum strains as potential probiotic cultures with cholesterol-lowering activity. Journal of Dairy Science, 96, 2746-2753. https://doi.org/10.3168/jds.2012-6123

102. Rodrigues, K. L., Caputo, L. R., Carvalho, J. C., Evangelista, J., \& Schneedorf, J. M. (2005). Antimicrobial and healing activity of kefir and kefiran extract. International Journal of Antimicrobial Agents, 25, 404-408. https://doi.org/10.1016/j.ijantimicag.2004.09.020

103. Carasi, P., Racedo, S. M., Jacquot, C., Romanin, D. E., Serradell, M. A., \& Urdaci, M. C. (2015). Impact of kefir derived lactobacillus kefiri on the mucosal immune response and gut microbiota. Journal of Immunology Research, 2015, 1-12. https://doi. org $/ 10.1155 / 2015 / 361604$

104. Hatmal, M. M., Nuirat, A., Zihlif, M. A., \& Taha, M. O. (2018). Exploring the influence of culture conditions on kefir's anticancer properties. Journal of Dairy Science, 101(5). https://doi.org/10.3168/jds.2017-13539 
105. Diosma, G., Romanin, D. E., Rey-Burusco, M. F., Londero, A., \& Garrote, G. L. (2014). Yeasts from kefir grains: Isolation, identification, and probiotic characterization. World Journal of Microbiology and Biotechnology, 1-11. https://doi.org/10.1007/s11274-0131419-9

106. Golowczyc, M. A., Gugliada, M. J., Hollmann, A., Delfederico, L., Garrote, G. L., Abraham, A. G., Semorile, L., \& De Antoni, G. (2008). Characterization of homofermentative lactobacilli isolated from kefir grains: Potential use as probiotic. Journal of Dairy Research, 75, 211-217. https://doi.org/10.1017/S0022029908003117

107. Fathi, Y., Faghih, S., Zibaeenezhad, M. J., \& Tabatabaei, S. H. R. (2016). Kefir drink leads to a similar weight loss, compared with milk, in a dairy-rich non-energy-restricted diet in overweight or obese premenopausal women: a randomized controlled trial. European Journal of Nutrition, 55(1). https://doi.org/10.1007/s00394-015-0846-9

108. Bengoa, A. A., Iraporda, C., Garrote, G. L., \& Abraham, A. G. (2019). Kefir microorganisms: their role in grain assembly and health properties of fermented milk. Journal of Applied Microbiology, 126(3), 686-700. https://doi.org/10.1111/jam.14107

109. Pražnikar, Z. J., Kenig, S., Vardjan, T., Bizjak, M. Č., \& Petelin, A. (2020). Effects of kefir or milk supplementation on zonulin in overweight subjects. Journal of Dairy Science, 103(5), 3961-3970. https://doi.org/10.3168/jds.2019-17696

110. Ogawa, M., Saiki, A., Matsui, Y., Tsuchimoto, N., Nakakita, Y., Takata, Y., \& Nakamura, T. (2016). Effects of oral intake of heat-killed Lactobacillus brevis SBC8803 (SBL88 ${ }^{\mathrm{TM}}$ ) on dry skin conditions: A randomized,double-blind,placebo-controlled study. Experimental and Therapeutic Medicine, 12(6), 3863-3872. https://doi.org/10.3892/etm.2016.3862

111. Alves, E., Rijo, P., Rodrigues, L. M., \& Rosado, C. (2021). Acceptability of kefir produced by fermentation of Portuguese milk with CIDCA AGK1 grains in a sample of Portuguese consumers. Biomedical and Biopharmaceutical Research, 18(1), 1-9. https://doi. org/10.19277/BBR.18.1.252

112. Dimidi, E., Cox, S., Rossi, M., \& Whelan, K. (2019). Fermented Foods : Definitions and Characteristics , Gastrointestinal Health and Disease. Nutrients, 11(1806), 1-26.

113. Dallas, D., Citerne, F., Tian, T., Silva, V., Kalanetra, K., Frese, S., Robinson, R., Mills, D., \& Barile, D. (2016). Peptidomic analysis reveals proteolytic activity of kefir microorganisms on bovine milk proteins. Food Chemistry, 197(0 0), 273-284. https://doi. org/10.1016/j.foodchem.2015.10.116

114. Tung, Y. T., Chen, H. L., Wu, H. S., Ho, M. H., Chong, K. Y., \& Chen, C. M. (2018). Kefir Peptides Prevent Hyperlipidemia and Obesity in High-Fat-Diet-Induced Obese Rats via Lipid Metabolism Modulation. Molecular Nutrition and Food Research, 62(3). https://oi. org/10.1002/mnfr.201700505

115. Ahmed, Z., Wang, Y., Ahmad, A., Khan, S. T., Nisa, M., Ahmad, H., \& Afreen, A. (2013). Kefir and Health: A Contemporary Perspective. Critical Reviews in Food Science and Nutrition, 53(5), 422-434. https://doi.org/10.1080/10408398.2010.540360

116. Wang, Y., Ahmed, Z., Feng, W., Li, C., \& Song, S. (2008). Physicochemical properties of exopolysaccharide produced by Lactobacillus kefiranofaciens ZW3 isolated from Tibet kefir. International Journal of Biological Macromolecules, 43, 283-288. https://doi. org/10.1016/j.ijbiomac.2008.06.011

117. Hamet, M. F., Medrano, M., Pérez, P. F., \& Abraham, A. G. (2016). Oral administration of kefiran exerts a bifidogenic effect on BALB/c mice intestinal microbiota. Beneficial Microbes, 7(2), 237-246. https://doi.org/10.3920/BM2015.0103

118. Serafini, F., Turroni, F., Ruas-Madiedo, P., Lugli, G. A., Milani, C., Duranti, S., Zamboni, N., Bottacini, F., van Sinderen, D., Margolles, A., \& Ventura, M. (2014). Kefir fermented milk and kefiran promote growth of Bifidobacterium bifidum PRL2010 and modulate its gene expression. International Journal of Food Microbiology, 178, 50-59. https://doi.org/10.1016/j.ijfoodmicro.2014.02.024

119. Rodrigues, K. L., Carvalho, J. C. T., \& Schneedorf, J. M. (2005). Anti-inflammatory properties of kefir and its polysaccharide extract. Inflammopharmacology, 13(5-6), 485-492. https://doi.org/10.1163/156856005774649395

120. Chen, Z., Shi, J., Yang, X., Nan, B., Liu, Y., \& Wang, Z. (2015). Chemical and physical characteristics and antioxidant activities of the exopolysaccharide produced by Tibetan kefir grains during milk fermentation. International Dairy Journal, 43, 15-21. https://doi. org/10.1016/j.idairyj.2014.10.004

121. Kim, J. H., Kim, K., Kanjanasuntree, R., \& Kim, W. (2019). Kazachstania turicensis CAU Y1706 ameliorates atopic dermatitis by regulation of the gut-skin axis. Journal of Dairy Science, 102(4), 2854-2862. https://doi.org/10.3168/jds.2018-15849

122. Bekar, O., Yilmaz, Y., \& Gulten, M. (2010). Kefir Improves the Efficacy and Tolerability of Triple Therapy in Eradicating Helicobacter pylori. Journal of Medicinal Food, 14(4), 344-347. https://doi.org/10.1089/jmf.2010.0099

123. Maki, R., Matsukawa, M., Matsuduka, A., Hashinaga, M., Anai, H., Yamaoka, Y., Hanada, K., \& Fujii, C. (2018). Therapeutic effect of lyophilized, Kefir-fermented milk on constipation among persons with mental and physical disabilities. Japan Journal of Nursing Science, 15(3), 218-225. https://doi.org/https://doi.org/10.1111/jjns.12189

124. Kim, D. H., Jeong, D., Kim, H., \& Seo, K. H. (2019). Modern perspectives on the health benefits of kefir in next generation sequencing era: Improvement of the host gut microbiota. Critical Reviews in Food Science and Nutrition, 59(11), 1782-1793. https://doi.org/10.1 080/10408398.2018.1428168

125. Azizi, N. F., Kumar, M. R., Yeap, S. K., Abdullah, J. O., Khalid, M., Omar, A. R., Osman, M. A., Mortadza, S. A. S., \& Alitheen, N. B. (2021). Kefir and its biological activities. Foods, 10(6), 1-26. https://doi.org/10.3390/foods10061210

126. Bellikci-Koyu, E., Sarer-Yurekli, B. P., Akyon, Y., Aydin-Kose, F., Karagozlu, C., Ozgen, A. G., Brinkmann, A., Nitsche, A., Ergunay, K., Yilmaz, E., \& Buyuktuncer, Z. (2019). Effects of Regular Kefir Consumption on Gut Microbiota in Patients with Metabolic Syndrome: A Parallel-Group, Randomized, Controlled Study. Nutrients, 11(9), 2089. https://doi.org/10.3390/nu11092089

127. Peluzio, M. do C. G., Dias, M. de M. e., Martinez, J. A., \& Milagro, F. I. (2021). Kefir and Intestinal Microbiota Modulation: Implications in Human Health. Frontiers in Nutrition, 8(February), 1-15. https://doi.org/10.3389/fnut.2021.638740

128. Stiemsma, L. T., Nakamura, R. E., Nguyen, J. G., \& Michels, K. B. (2020). Does Consumption of Fermented Foods Modify the Human Gut Microbiota? Journal of Nutrition, 150(7), 1680-1692. https://doi.org/10.1093/jn/nxaa077 